\title{
STRUCTURAL ANALYSIS OF IN-PLANE LOADED CLT BEAMS
}

\author{
Mario Jeleč \\ Josip Juraj Strossmayer University of Osijek, Faculty of Civil Engineering Osijek, mag.ing.aedif. \\ Corresponding author: mjelec@gfos.hr \\ Kristina Strukar \\ Josip Juraj Strossmayer University of Osijek, Faculty of Civil Engineering Osijek, univ.bacc.ing.aedif. \\ Vlatka Rajčić \\ University of Zagreb, Faculty of Civil Engineering Zagreb, Full Professor
}

Scientiffic paper / Znanstveni rad

\begin{abstract}
Cross laminated timber $(C L T)$ is a versatile engineered timber product that is increasingly well-known and of global interest in several applications such as full size plane or linear timber elements. The aim of this study involves investigating the performance of CLT beams loaded in-plane by considering bending and shear stress analysis with a special emphasis on the in-plane shear behavior including the complex internal structure of CLT. Numerical analysis based on 3D-FE models was used and compared with two existing analytical approaches, namely representative volume sub element (method I) and composite beam theory (method II). The separate verification of bending and shear stresses including tree different shear failure modes was performed, and a good agreement was obtained. The main difference between the results relates to shear failure mode in the crossing areas between the orthogonally bonded lamellas in which the distribution of shear stresses $I_{z x}$ over the crossing areas per height of the CLT beam is not in accordance with the analytical assumptions. The presented analyses constitute the first attempt to contribute to the on-going review process of Eurocode 5 with respect to CLT beams loaded-in plane. Currently, regulations on designing these types of beams do not exist, and thus experimental and numerical investigations are planned in the future.
\end{abstract}

Keywords: cross laminated timber; in-plane loading; FE-analysis; shear stress; normal stress; shear failure modes

\section{ANALIZA NOSIVOSTI CLT GREDA OPTEREĆENIH U RAVNINI ELEMENTA}

Sažetak: Križno lamelirano drvo (CLT) svestrani je inženjerski proizvod na bazi drveta koji je sve poznatiji i globalne važnosti u različitim primjenama poput pločastih i linijskih elemenata velikih dimenzija. Prikazani rad usmjeren je na istraživanje ponašanja CLT greda opterećenih u ravnini elementa, uzimajući u obzir analizu naprezanja od savijanja i posmika, s naglaskom na posmična naprezanja u ravnini elementa i složenu unutrašnju strukturu CLTa. Numerička analiza bazirana na 3D-FE modelima uspoređena je s dvama postojećim analitičkim pristupima pod nazivom reprezentativni volumni pod element (metoda I) i kompozitna štapna teorija (metoda II). Provedena je odvojena verifikacija naprezanja od savijanja i posmika uzimajući u obzir tri različita posmična mehanizma sloma, pri čemu je dobiveno dobro slaganje rezultata. Glavna razlika među rezultatima vezana je za posmični mehanizam sloma na kontaktu ortogonalno lijepljenih lamela, gdje se raspodjela posmičnih naprezanja $\mathrm{T}_{x z}$ po lijepljenom kontaktu po visini CLT grede ne poklapa s teoretskim pretpostavkama. Prikazana analiza početni je doprinos trenutačno revidiranog Eurokoda 5, vezano za CLT grede opterećene u ravnini elementa. Trenutačno ne postoje propisi za njihovo dimenzioniranje pa su stoga daljnja eksperimentalna i numerička istraživanja ove tematike u planu.

Ključne riječi: križno lamelirano drvo; opterećenje u ravnini; numerička analiza; posmično naprezanje; normalno naprezanje; posmični mehanizam sloma 


\section{INTRODUCTION}

Cross-laminated timber (CLT) is a versatile engineered timber product that is increasingly well known and of global interest. Specifically, CLT presents a two-dimensional plate-like laminated prefabricated product and is generally composed of an uneven number of orthogonally bonded layers that are capable of carrying both in- and out-ofplane loads and used for wall or floor elements as well as linear members (Figure 1).

Although CLT possesses evident benefits, it is still not included in the European timber design code Eurocode 5 [1]. With respect to CLT under out-of-plane loading (e.g. floor elements), test configurations and strength values are well agreed upon and several design procedures are proposed in design handbooks and technical provisions [2]. With respect to CLT under in- plane loading (e.g. wall elements or beam elements), a few properties and failure modes, such as in-plane shear strength, are still under discussion and presently result in conservative regulations [2].

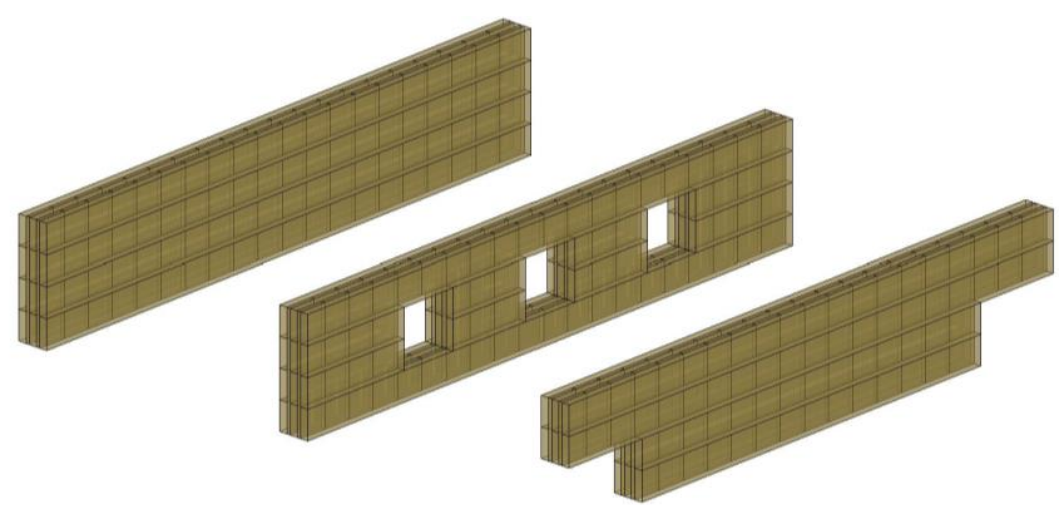

Figure 1 Different applications of CLT linear elements loaded in-plane

The aim of this study involves investigating the performance of CLT beams loaded in-plane with a special emphasis on shear loading and the in-plane shear behavior by considering the complex internal structure. Specifically, CLT beams offer several advantages over solid or glued laminated timber beams due to their specific layup of orthogonally bonded layers and especially in applications in which shear stresses and tensile stresses perpendicular to the beam axis are critical for the load carrying capacity such as in beams with holes or notched beams as shown in Figure 1. Additionally, shear stresses may limit the load-carrying capacity as opposed to normal stresses in a few other applications in which deep and short span CLT beams are used, such as lintels. Numerical results based on 3D-FE analysis are presented and compared with the existing two analytical models to obtain an in-depth understanding of the local mechanical behavior in shear stress transfer between laminations.

\section{ANALYTICAL MODEL OF CLT ELEMENTS LOADED IN-PLANE}

\subsection{Failure modes}

Normal and shear stresses occur in CLT beams exposed to in-plane loading. Only the bending resistance of the net cross section area is considered to verify normal stresses and implies layers with boards oriented in the direction of stress [3]. The contribution of transversal layers $\left(\alpha=90^{\circ}\right)$ is neglected due to a high $\mathrm{MoE}$ ratio, typically with $E_{0} / E_{90}$ $\approx 30-40$. In order to verify shear strength, it is necessary to consider three different shear failure mechanisms based on extant studies $[4,5]$ and according to the existence of adhesive bonding between the narrow faces (Figure 2):

- Failure mode I (FM I) or gross shear failure of the CLT element by shear failures in all layers of CLT with narrow face bonded layers

- Failure mode II (FM II) or net shear failure of the CLT element by shear failure in net cross sections of CLT

- Failure mode III (FM III) or torsion failure in the crossing areas between orthogonally bonded lamellae involving torsional and unidirectional shear stresses 

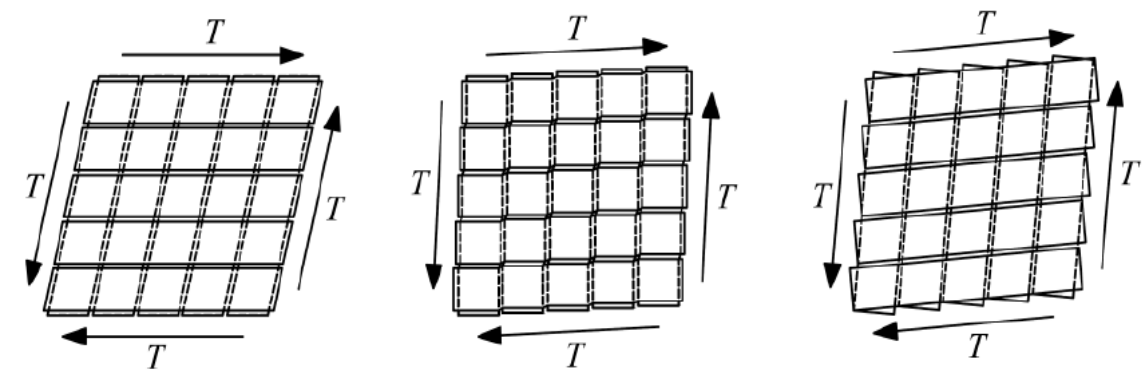

Figure 2 Shear failure modes I, II and III in CLT elements loaded in-plane (from left to right) [5]

\subsection{Analytical method I: RVSE method}

An efficient mechanical model for internal stress verification was proposed by Moosbrugger et al. to evaluate shear stresses in a CLT element loaded in-plane [6,7]. The evaluated method is based on a representative volume element (RVE) as the smallest unit with thickness equal to a CLT element and width and depth equal to the width of a board plus the half the width of gaps between the adjacent boards. In the case of CLT with constant layer thicknesses and infinite number of layers, the RVE is further reduced to an elementary representative volume sub element (RVSE) that represents the smallest unit cell at an intersection between two orthogonal boards with an internal stress state describing the global behavior of the CLT element (Figure 3).
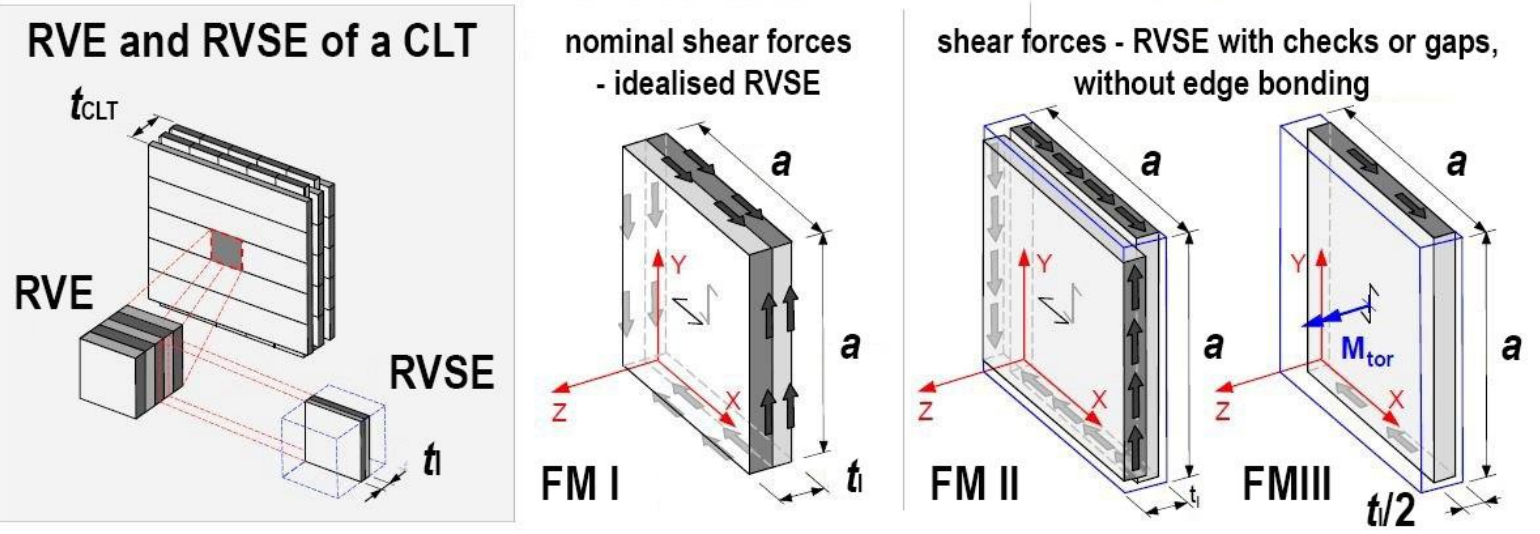

Figure 3 RVSE method for verification of shear stresses in CLT elements loaded in-plane [7]

The calculation of shear stresses is based on idealized nominal shear stress $T_{0}$ that occurs in case of edge bonded boards and actually corresponds to FM I based on Eqn. 1. Additionally, FM II is based on net shear stresses $I_{\text {net }}$ and FM III on torsional shear stresses $I_{\text {tor }}$ according to Eqn. 2 and 3 [7] as follows:

$T_{0}=\frac{V_{\mathrm{xy}, \mathrm{RVSE}}}{a \cdot t_{\mathrm{l}}}(\mathrm{FMl})$

$T_{\text {net }}=2 \cdot T_{0} \quad(\mathrm{FMII})$

$T_{\text {tor }}=\frac{M_{\text {tor }}}{l_{\mathrm{P}}} \cdot \frac{a}{2}=\frac{3 \cdot T_{0} \cdot t_{1}}{a} \quad(\mathrm{FMIII})$

where

$V_{\mathrm{xy}, \text { RVSE }} \quad$ proportional shear force of an individual RVSE

a board width

$t_{1} \quad$ board thickness

$M_{\text {tor }} \quad$ torsional moment in the crossing area of an individual RVSE

$I_{p} \quad$ polar moment of the inertia of crossing area 
In the design of CLT elements, it is necessary to verify each of the stress components with respect to the corresponding shear strength related to a relevant shear failure mode based on Eqn. 4 [7] as follows:

(FMI) $\frac{T_{0}}{f_{\mathrm{v}, \text { lam }}} \leq 1.0$; (FMII) $\frac{T_{\text {net }}}{f_{\mathrm{v}, \text { net }}} \leq 1.0$; (FMIII) $\frac{T_{\text {tor }}}{f_{\mathrm{v}, \text { tor }}} \leq 1.0$

where

$f_{\mathrm{v}, \mathrm{lam}} \quad$ shear strength of gross cross section

$f_{v, \text { net }} \quad$ shear strength of net cross section

$f_{\text {tor }} \quad$ torsional strength

In case of CLT elements without constant thickness of layers or CLT with an odd number of layers $(3,5$ or 7$)$ in which the number of layers is not identical in both main directions, a real CLT lay-up must be considered to verify failure modes in which examples for 3 and 5 layered CLT elements are shown in previous studies $[7,8]$.

\subsection{Analytical method II: Composite beam theory}

With respect to CLT beams exposed to both bending and shear loading, a design procedure is proposed based on the theory of composite beams to verify shear stresses [5, 9]. In the case of FM I and FM II, shear stresses $T_{x y}$, causing failure parallel and perpendicular to the grain are evaluated by using Bernoulli-Euler beam theory $[5,9]$ as follows:

$$
\begin{gathered}
I_{x y, \text { gross }}=\frac{V_{y} \cdot S_{z, \text { gross }}}{I_{z, \text { gross }} \cdot t_{\text {gross }}}(\mathrm{FMI}) \\
I_{\text {xy,net }}=\frac{V_{y} \cdot S_{z, \text { net }}}{I_{z, \text { net }} \cdot t_{\text {net }}}(\mathrm{FMII})
\end{gathered}
$$

The maximum values are calculated as peak values of the parabolic functions based on Eqn. 7 and 8 (Figure 4) $[5,9]$ as follows:

$$
\begin{gathered}
I_{\text {xy,gross,max }}=1.50 \frac{V_{y}}{h \cdot t_{\text {gross }}} \quad(\mathrm{FMI}) \\
I_{\text {xy,net,max }}=1.50 \frac{V_{y}}{h \cdot t_{\text {net }}} \quad(\mathrm{FMII})
\end{gathered}
$$

where
$V_{y} \quad$ shear force
$S_{z} \quad$ static moment about z-axis
$I_{z} \quad$ second moment of inertia about z-axis
$t \quad$ thickness of the CLT beam
gross complete/total cross section
net net cross section including either the longitudinal or the transversal layers only

An example of shear stress distribution along the longitudinal and transversal layers of CLT beam with four lamellae in the longitudinal layers is shown in Figure 4. Based on extant studies [5, 9], in case of an even number of lamellae in the longitudinal layers, Eqn. 7 overestimates the maximum shear stress in the gross cross section (Figure 4). Conversely, in the case of an odd number of lamellae in the longitudinal layers, the maximum net shear stresses are overestimated by Eqn. 8. However, the error decreases rapidly with increases in the number of lamellae in the longitudinal layers [9]. 


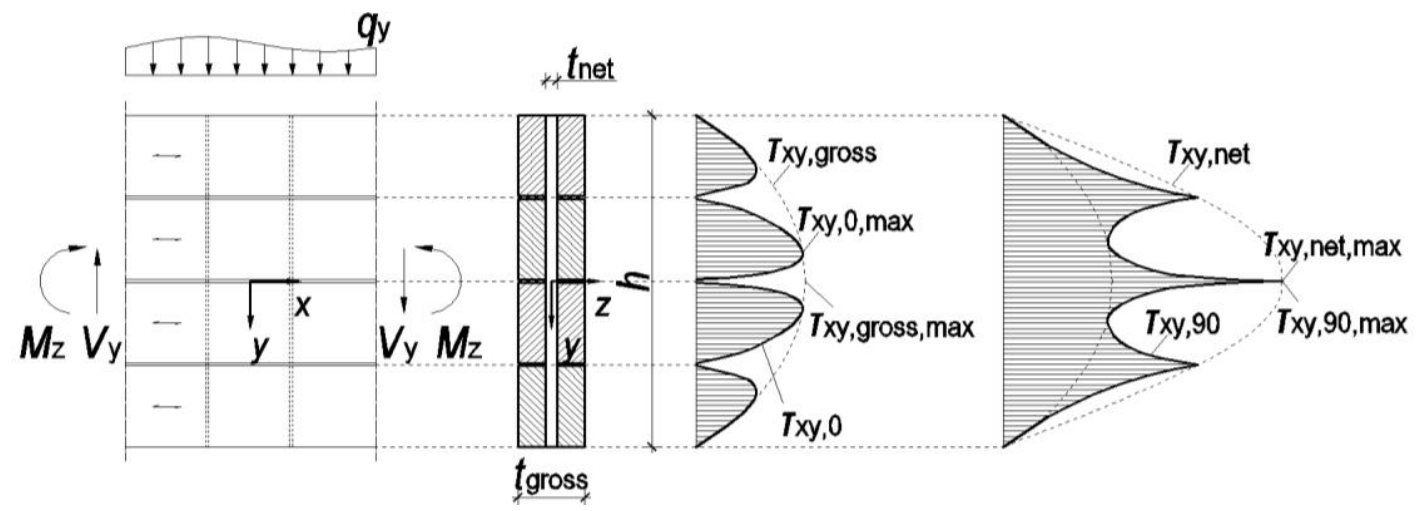

Figure 4 Distribution of shear stresses in the lamellae of CLT beam with four longitudinal lamellae as follows: shear stress $T_{\mathrm{xy}, 0}$ in longitudinal lamellae (left) and shear stress $T_{\mathrm{xy}, 90}$ in transversal lamellae (right)

In the case of FM III, a total of three components of shear stress participate in load transfer within the crossing areas between the orthogonally bonded lamellae $[5,9]$ as follows: shear stresses parallel to the beam axis $\left(\tau_{\mathrm{zx}}\right)$, torsional shear stresses $\left(\tau_{\text {tor }}\right)$, and shear stresses perpendicular to the beam axis $\left(\tau_{z y}\right)$.

The shear stresses parallel to the beam axis, $T_{\mathrm{zx}}$, are caused by a variation in the bending moment as a function of the $x$-coordinate. The maximum value of the stresses is obtained at the outermost lamellae of the beam that corresponds well with numerical analysis in a previous study [10]. The maximum value of the shear stress parallel to the beam axis is derived from the model of composite beam and is calculated based on extant studies $[5,9]$ as follows:

$I_{z x}=\frac{6 V_{y}}{b^{2} \cdot n_{\mathrm{CA}}} \cdot\left(\frac{1}{m^{2}}-\frac{1}{m^{3}}\right)$

where

$b \quad$ width of lamellae

$n_{\mathrm{CA}} \quad$ number of crossing areas within the beam thickness

$m \quad$ number of longitudinal lamellae within the beam height

Torsional stresses, $T_{\text {tor, }}$ which are also derived based on the model of a composite beam, arise due to the eccentricity between the centerlines of adjacent lamellae. According to a previous study [9], equal torsional moments and subsequently equal torsional shear stresses are assumed for all crossing areas in the beam height direction based on the condition that the lamellae in the transversal layers are assumed to remain straight in the deformed beam. A preliminary numerical analysis [10] indicates that torsional moments as well as torsional stresses are higher in the crossing areas close to the neutral axis and lower at crossing areas closer to the upper and lower sides of the beam. According to the analytical model [6], given equal torsional moments for all crossing areas in the beam height direction, the maximum torsional shear stress is calculated based on a previous study $[5,9]$ as follows:

$T_{\text {tor }}=\frac{3 V_{\mathrm{y}}}{b^{2} \cdot n_{\mathrm{CA}}} \cdot\left(\frac{1}{m}-\frac{1}{m^{3}}\right)$

According to a previous study [9], Eqn. 9 and Eqn. 10 provide accurate results for CLT beams with a constant ratio $t_{\text {long,k }} \mid n_{c a, k}$ between the thickness of an individual longitudinal layer and the number of glue lines that are shared by the respective layer with adjacent transversal layers. In this case, shear stresses $I_{\mathrm{zx}}$ and $I_{\text {tor }}$ are constant across the beam thickness. Hence, Eqn. 8 and Eqn. 9 are derived based on an "ideal" cross section lay-up (for e.g., obtained by using double centric layers of boards of equal thickness as the outer longitudinal layers or using a centric layer of boards with twice the thickness of the boards in the outer longitudinal layers). However, the variation of shear stresses $\tau_{\mathrm{zx}}$ and $\tau_{\mathrm{tor}}$ is small within the range of layups that are used in practice and especially for CLT beams composed of softwood with MoE of the lamellae approximately corresponding to $11000 \mathrm{~N} / \mathrm{mm}^{2}[9]$. 
Shear stresses perpendicular to the beam axis, $\tau_{z y}$, arise due to external loads such as support reactions or external forces. With respect to a CLT beam exposed to an external force $q_{y}[\mathrm{~N} / \mathrm{m}]$ applied to the end grain of the transversal layers, shear stresses are evaluated based on Eqn. 11 [5] as follows:

$T_{z y}=\frac{q_{y}}{m \cdot b \cdot n_{\mathrm{CA}}}$

In the design of CLT beams, it is necessary to verify each of the stress components with the corresponding shear strength related to a relevant shear failure mode. Additionally, it is necessary to consider the interaction of shear stresses in the crossing areas. Based on a previous study [5, 9], it is necessary to consider two interactions to verify FM III as follows:

(FMIII - A) $\frac{T_{z x}}{f_{\mathrm{r}}}+\frac{T_{\text {tor }}}{f_{\text {tor }}} \leq 1.0$; (FMIII- B) $\frac{T_{z y}}{f_{\mathrm{r}}}+\frac{T_{\text {tor }}}{f_{\text {tor }}} \leq 1.0$

where $f_{r}$ denotes the rolling shear strength and $f_{\text {tor }}$ denotes torsional shear strength.

\section{NUMERICAL FE- ANALYSIS}

\subsection{Geometry parameters}

This study focuses on shear strength verification, geometry parameters, and load configuration of numerical models based on the reference shear-beam proposed by Gehri [11]. Geometry parameters are presented in Table 1 with the labels marked on Figure. 5. Two series of beams were modeled with total heights corresponding to $600 \mathrm{~mm}$ and $300 \mathrm{~mm}$, respectively. For each individual series, two different layups were used including 3 and 5 -layered CLT beams. With respect to each model, the width of lamellae $b$ was varied in steps of $100 \mathrm{~mm}, 150 \mathrm{~mm}$, and $200 \mathrm{~mm}$, since values between $90 \mathrm{~mm}$ and $230 \mathrm{~mm}$ are mainly used in producing CLT based on a previous study [2]. Thickness of each layer was used as constant value, namely $t_{0}=40 \mathrm{~mm}$ for longitudinal and $t_{90}=20 \mathrm{~mm}$ for transversal layers.

Table 1 Dimensions and layup of analyzed CLT beams

\begin{tabular}{|c|c|c|c|c|c|c|c|}
\hline Model & $L[\mathrm{~mm}]$ & $h[\mathrm{~mm}]$ & $t_{\text {gross }[\mathrm{mm}]}$ & $t_{0}[\mathrm{~mm}]$ & $t_{90}[\mathrm{~mm}]$ & $b[\mathrm{~mm}]$ & layup \\
\hline \multirow{3}{*}{$\mathrm{H} 600-5$} & \multirow{3}{*}{2400} & \multirow{3}{*}{600} & \multirow{3}{*}{160} & \multirow{3}{*}{40} & \multirow{3}{*}{20} & 200 & \multirow{3}{*}{$|-c-|-c-\mid$} \\
\hline & & & & & & 150 & \\
\hline & & & & & & 100 & \\
\hline \multirow{3}{*}{$\mathrm{H} 600-3$} & \multirow{3}{*}{2400} & \multirow{3}{*}{600} & \multirow{3}{*}{100} & \multirow{3}{*}{40} & & 200 & \multirow{3}{*}{$|-c-|$} \\
\hline & & & & & 20 & 150 & \\
\hline & & & & & & 100 & \\
\hline \multirow{2}{*}{ H300-5 } & \multirow{2}{*}{1200} & \multirow{2}{*}{300} & \multirow{2}{*}{160} & \multirow{2}{*}{40} & \multirow{2}{*}{20} & 150 & \multirow{2}{*}{$|-C-|-c-\mid$} \\
\hline & & & & & & 100 & \\
\hline \multirow{2}{*}{$\mathrm{H} 300-3$} & \multirow{2}{*}{1200} & \multirow{2}{*}{300} & \multirow{2}{*}{100} & \multirow{2}{*}{40} & \multirow{2}{*}{20} & 150 & \multirow{2}{*}{$|-c-|$} \\
\hline & & & & & & 100 & \\
\hline
\end{tabular}

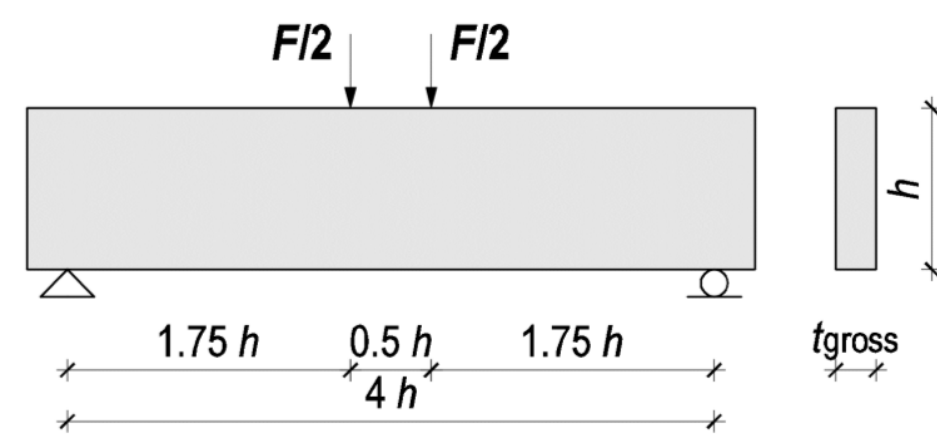

Figure 5 Geometrical properties of analyzed CLT beams 


\subsection{Material parameters}

The beams were modeled as a layered structure with each layer consisting of laminations (boards). The boards are assumed as perfectly bonded only on their flat faces while edge bonding is not assumed. This simplification is based on the assumption that development of cracks is expected due to moisture and temperature variations even in the case in which boards are glued over narrow faces. Thus, contact on the narrow faces between the boards is limited at least to the core layers [2]. The perfect bond between the flat face areas of the boards was modeled by using contact elements of ANSYS 17 software. The lamination material is assumed as linear elastic and transverse isotropic using strength class T14 based on EN 14080 [12] as shown in Table 2. The double symmetry of the test set-up is considered, and thus only one quarter of each setup is modeled. Element mesh size was based on sensitivity analysis, and a uniform value corresponding to $5 \times 5 \times 5 \mathrm{~mm}^{3}$ was set in the zones of relevance in which stresses were evaluated while a coarser mesh size was used in the more distant areas as shown in Figure 6.

Table 2 Material properties of analyzed CLT beams

\begin{tabular}{ccccccccc}
\hline $\begin{array}{c}E_{\mathrm{x}} \\
{\left[\mathrm{N} / \mathrm{mm}^{2}\right]}\end{array}$ & $\begin{array}{c}E_{\mathrm{y}} \\
{\left[\mathrm{N} / \mathrm{mm}^{2}\right]}\end{array}$ & $\begin{array}{c}E_{\mathrm{z}} \\
{\left[\mathrm{N} / \mathrm{mm}^{2}\right]}\end{array}$ & $\begin{array}{c}V_{\mathrm{xy}} \\
{[-]}\end{array}$ & $\begin{array}{c}V_{\mathrm{yz}} \\
{[-]}\end{array}$ & $\begin{array}{c}V_{\mathrm{xz}} \\
{[-]}\end{array}$ & $\begin{array}{c}G_{\mathrm{xy}} \\
{\left[\mathrm{N} / \mathrm{mm}^{2}\right]}\end{array}$ & $\begin{array}{c}G_{\mathrm{yz}} \\
{\left[\mathrm{N} / \mathrm{mm}^{2}\right]}\end{array}$ & $\begin{array}{c}G_{\mathrm{xz}} \\
{\left[\mathrm{N} / \mathrm{mm}^{2}\right]}\end{array}$ \\
\hline 11000 & 370 & 370 & 0.35 & 0.35 & 0.35 & 690 & 69 & 690 \\
\hline
\end{tabular}
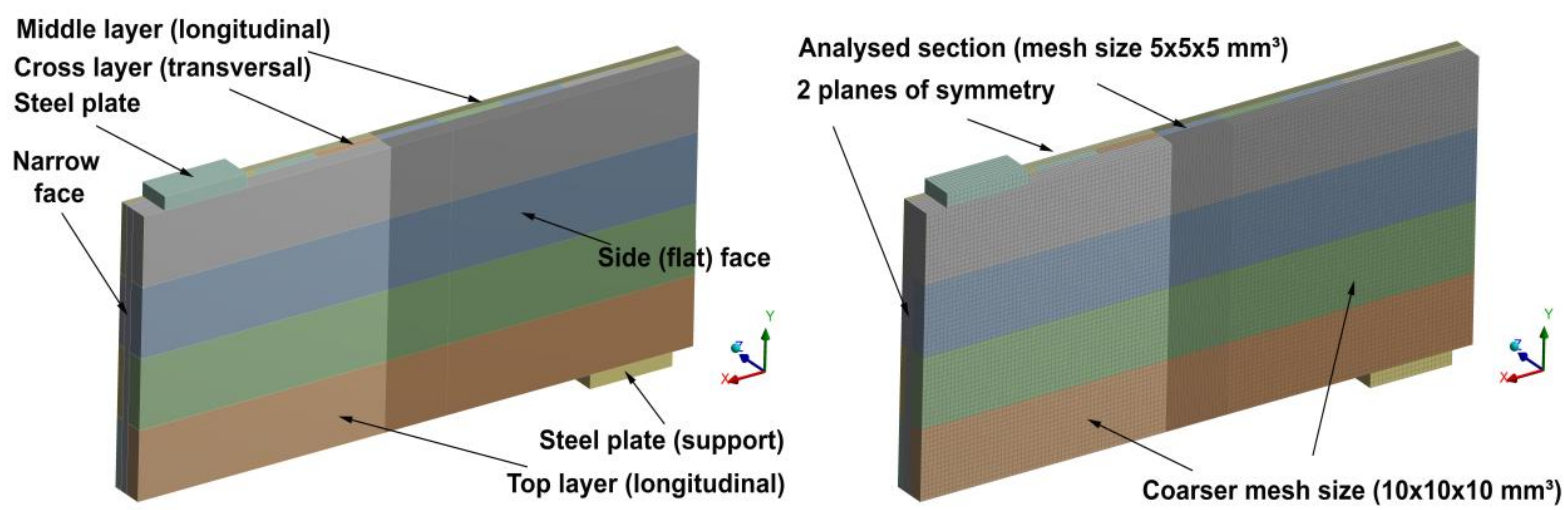

Figure 6 Labels of CLT beams (left) and mesh size (right)

\section{DISCUSSION AND COMPARISON OF RESULTS}

\subsection{Bending stress analysis}

The numerical results were compared with the analytical results. The mean value of bending stresses $\sigma_{\mathrm{m}, \text { net }}$ relative to the net area at the mid span of the beam was calculated (Figure 7) and compared with values obtained by Eqn. 13. The summarized results are presented in Table 3 , and a good agreement is generally obtained. This is expressed as follows:

$\sigma_{\mathrm{m}, \mathrm{net}}=\frac{M_{\mathrm{L} / 2}}{W_{\text {net }}}=\frac{5.25 \cdot F_{\max } \cdot h}{t_{0, \text { net }} \cdot h^{2}}$ 
Table 3 Summarized results of normal stresses $\sigma_{\mathrm{x}}$ due to bending

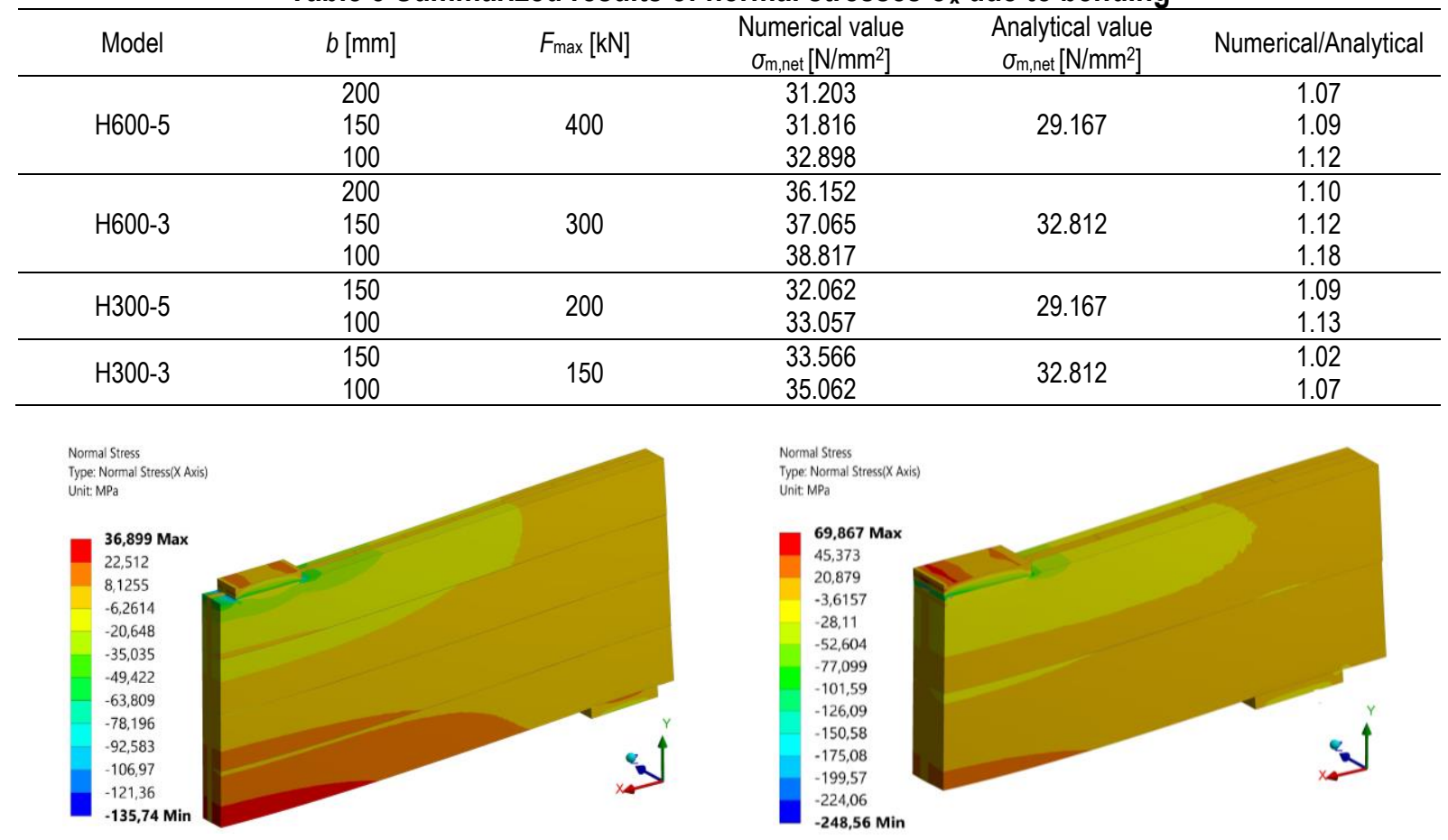

Figure 7 Normal stresses $\sigma_{x}$ for model H600-5 (left) and model H300-5 (right) for $b=150 \mathrm{~mm}$

\subsection{Shear stress analysis}

Verification of each stress component was performed in the shear stress analysis and included the shear stresses in gross and net sections as well as over crossing areas of laminations. Results of shear stresses $T_{\mathrm{xy}}$ and $T_{\mathrm{zx}}$ in transversal lamellae located between the load point and support are presented in Figure 8 for model H600-5 in the case of $b=150 \mathrm{~mm}$.
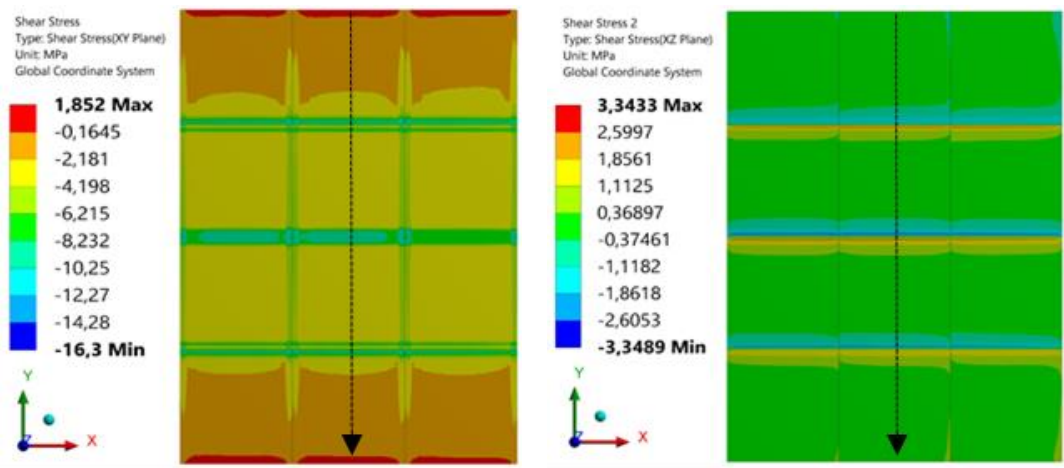

Figure 8 Shear stresses $T_{x y}$ (left) and shear stresses $T_{x z}$ (right) in model H600-5

The distribution of shear stresses $T_{x y}$ and $T_{x z}$ across the beam height is also presented for model $\mathrm{H} 600-5$ relative to five different stress paths in Figure 9 as follows: 1 ) at the center of outside longitudinal lamellae, 2) at the outside surface of transversal lamellae (over crossing areas), 3) at the center of transversal lamella, 4) at the inside surface of transversal lamellae (over crossing areas), and 5) at the center of the inside longitudinal lamellae. 


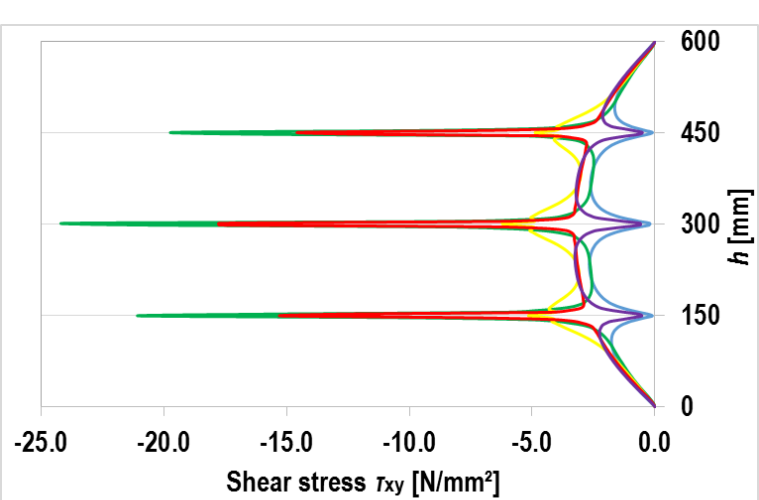

-1) тxy,0 -2) тxy,90-3) тxy,0 -4) тxy,90-5) тxy,0

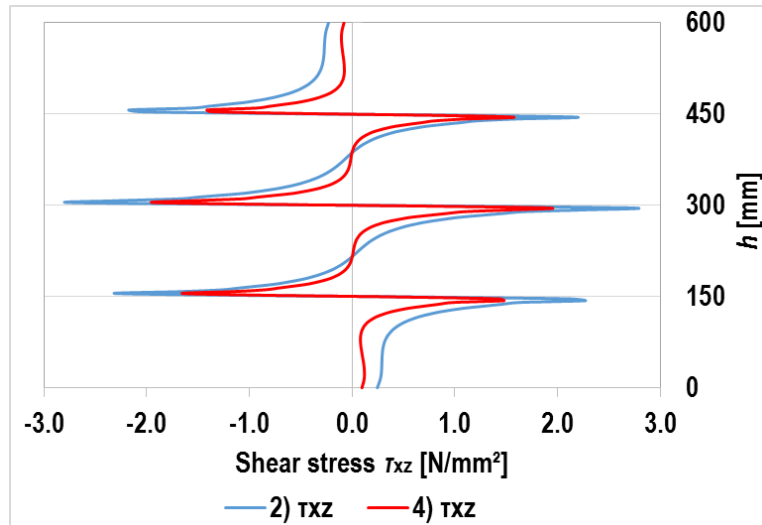

-2) $\mathrm{TXz} \quad-4) \mathrm{TXz}$

Figure 9 Distribution of shear stresses $T_{x y}$ (left) and shear stresses $T_{x z}$ (right) in model H600-5

As shown in the graphs, a non-uniform stress distribution in good agreement with the theoretical distribution is observed as shown in Figure 4. Thus, mean stresses over appropriate areas or paths were derived and compared with analytical values to verify each failure mode (FM I, FM II and FM III). In order to verify FM I, the maximum value of shear stress $T_{x y, 0}$ along a stress path across the center of the longitudinal lamellae (curve 1) of Figure 9 (left) is compared with the analytical values. With respect to FM II, evaluating the maximum value of the net shear stress $T_{x y, n e t}$ based on the FE-analyses is problematic because the stress distribution is highly non-uniform. Thus, mean values of net shear stresses $T_{x y}$,net across the critical cross sections of the transversal lamellae were obtained by integrating stresses (see Figure 10). This subsequently corresponds to the total shear force $F_{\mathrm{xy}}$ divided by the cross-sectional area of the transversal lamellae based on Eqn. 14. The summarized results of FM I and FM II are presented in Table 4 where better agreement is obtained in case of FM I and FM II with analytical methods II and I, respectively.

$I_{\text {xy,net,mean }}=\frac{\int T_{x y}}{A}=\frac{F_{x y}}{b \cdot t_{90}}$

Table 4 Summarized results for verification of FMI and FM II

\begin{tabular}{|c|c|c|c|c|c|c|c|}
\hline \multirow[b]{2}{*}{ Model } & \multirow[b]{2}{*}{$b[\mathrm{~mm}]$} & \multicolumn{3}{|c|}{$\mathrm{FM} \mid T_{\mathrm{xy}, 0}\left[\mathrm{~N} / \mathrm{mm}^{2}\right]$} & \multicolumn{3}{|c|}{ FM II $T_{\mathrm{xy}, \text {,net,mean }}\left[\mathrm{N} / \mathrm{mm}^{2}\right]$} \\
\hline & & $\begin{array}{c}\text { Numerical } \\
\text { method }\end{array}$ & $\begin{array}{c}\text { Analytical } \\
\text { method I }\end{array}$ & $\begin{array}{l}\text { Analytical } \\
\text { method II }\end{array}$ & $\begin{array}{c}\text { Numerical } \\
\text { method }\end{array}$ & $\begin{array}{c}\text { Analytical } \\
\text { method I }\end{array}$ & $\begin{array}{l}\text { Analytical } \\
\text { method II }\end{array}$ \\
\hline \multirow{3}{*}{$\mathrm{H} 600-5$} & 200 & 2.938 & & & 7.775 & & \\
\hline & 150 & 2.702 & 2.083 & 3.125 & 8.936 & 8.333 & 12.50 \\
\hline & 100 & 2.596 & & & 8.820 & & \\
\hline \multirow{3}{*}{$\mathrm{H} 600-3$} & 200 & 3.640 & & & 11.206 & & \\
\hline & 150 & 3.534 & 2.50 & 3.750 & 11.755 & 12. 50 & 18.75 \\
\hline & 100 & 3.472 & & & 11.611 & & \\
\hline \multirow[t]{2}{*}{ H300-5 } & 150 & 2.749 & 2.083 & 3.125 & 7.072 & 8.333 & 12.50 \\
\hline & 100 & 2.783 & & & 7.034 & & \\
\hline \multirow{2}{*}{ H300-3 } & 150 & 3.375 & 250 & 3750 & 9.906 & 1250 & 1875 \\
\hline & 100 & 3.568 & & & 9.941 & & \\
\hline
\end{tabular}

In case of FM III, it is necessary to verify the interaction between shear stresses in beam direction $T_{\mathrm{Zx}}$ and torsion shear stresses $I_{\text {tor }}$ over crossing areas [5]. In order to aid comparison with analytical expressions, mean stress values were calculated by integrating stresses over each crossing area (see Figure 10). In this aspect, the total (resultant) shear forces $F_{\mathrm{x}}$ and $F_{\mathrm{y}}$ as well as torsional moment $M_{\text {tor }}$ were obtained, and stresses were calculated based on (Eqn. 15, 16, and 17). In case of shear stress $T_{z y}$, the obtained numerical values were significantly small based on the theoretical background, and are therefore omitted. The summarized results of FM III are presented in 
Table 5, and only maximum values close to the neutral axis are shown in Figure 9 (right) and Figure 10 since the torsional stresses were not equal over each crossing area. The expressions are as follows:

$$
\begin{aligned}
& T_{\text {zx,cross,mean }}=\frac{\int T_{\mathrm{zx}}}{A_{\text {cross }}}=\frac{F_{\mathrm{x}}}{b \cdot b} \\
& T_{\text {zy,cross,mean }}=\frac{\int T_{\mathrm{zy}}}{A_{\text {cross }}}=\frac{F_{\mathrm{y}}}{b \cdot b} \\
& T_{\text {tor }}=\frac{M_{\text {tor }}}{I_{\mathrm{p}}} \cdot \frac{b}{2}
\end{aligned}
$$

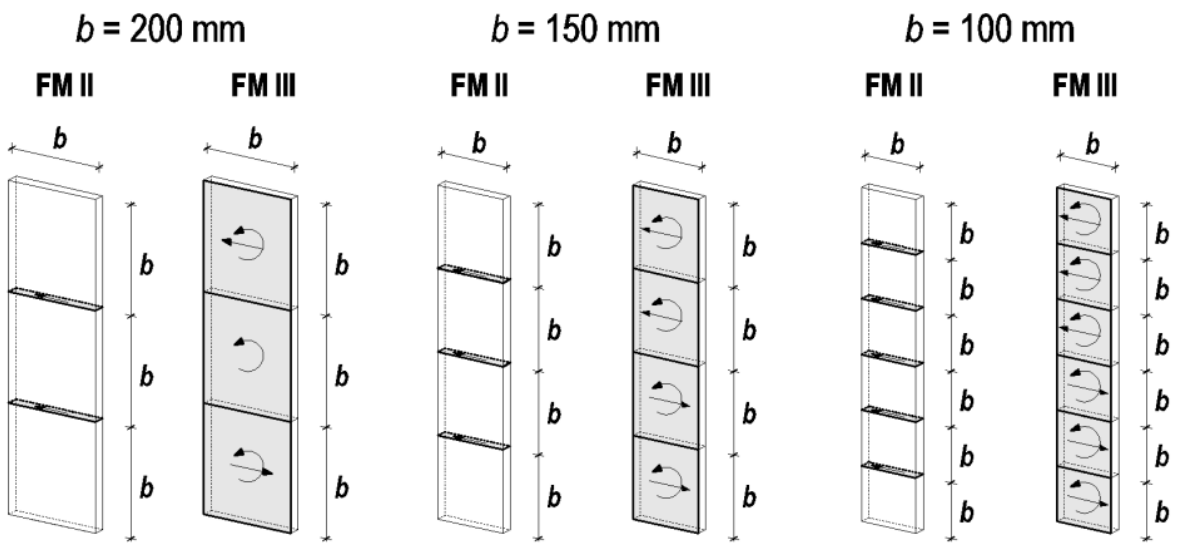

Figure 10 Cross-sectional areas for obtaining resultant forces in verification of FM II and FM III for model

\begin{tabular}{|c|c|c|c|c|c|c|}
\hline \multirow{2}{*}{ Model } & \multirow{2}{*}{$b[\mathrm{~mm}]$} & \multicolumn{2}{|c|}{ Numerical method } & \multirow{2}{*}{$\begin{array}{c}\begin{array}{c}\text { Analytical } \\
\text { method I }\end{array} \\
\begin{array}{c}\text { Ttor } \\
{\left[\mathrm{N} / \mathrm{mm}^{2}\right]}\end{array}\end{array}$} & \multicolumn{2}{|c|}{ Analytical method II } \\
\hline & & $\begin{array}{c}T_{\mathrm{zx}, \text { mean }} \\
{\left[\mathrm{N} / \mathrm{mm}^{2}\right]}\end{array}$ & $\begin{array}{c}T_{\text {tor }} \\
{\left[\mathrm{N} / \mathrm{mm}^{2}\right]}\end{array}$ & & $\begin{array}{c}T_{\mathrm{zx}} \\
{\left[\mathrm{N} / \mathrm{mm}^{2}\right]}\end{array}$ & $\begin{array}{c}T \text { tor } \\
{\left[\mathrm{N} / \mathrm{mm}^{2}\right]}\end{array}$ \\
\hline \multirow{3}{*}{$\mathrm{H} 600-5$} & 200 & 0.662 & 1.392 & 1.667 & 0.556 & 1.111 \\
\hline & 150 & 0.800 & 1.798 & 2.222 & 0.625 & 1.563 \\
\hline & 100 & 0.952 & 2.700 & 3.333 & 0.694 & 2.431 \\
\hline \multirow{3}{*}{$\mathrm{H} 600-3$} & 200 & 0.749 & 1.781 & 1.875 & 0.833 & 1.667 \\
\hline & 150 & 0.909 & 2.325 & 2.500 & 0.938 & 2.344 \\
\hline & 100 & 1.158 & 3.527 & 3.750 & 1.042 & 3.646 \\
\hline \multirow{2}{*}{$\mathrm{H} 300-5$} & 150 & 0.780 & 1.010 & 2.222 & 0.833 & 1.250 \\
\hline & 100 & 1.097 & 2.084 & 3.333 & 1.111 & 2.222 \\
\hline \multirow{2}{*}{ H300-3 } & 150 & 0.903 & 1.295 & 2.500 & 1.250 & 1.875 \\
\hline & 100 & 1.325 & 3.545 & 3.750 & 1.667 & 3.333 \\
\hline
\end{tabular}
$\mathrm{H} 600-5$ and $\mathrm{H} 600-3$

Table 5 Summarized results for verification of FM III

The results indicated that in most cases, the numerical values of torsional stresses $T_{\text {tor }}$ are between the analytical values of method I and method II. In case of unidirectional shear stresses $T_{x z}$, good agreement is obtained in most cases with the exception of model $\mathrm{H} 600$ with five layers since shear stresses were not constant in the beam thickness direction given the absence of a double centric layer on which the analytical approach is actually based. 


\section{CONCLUSIONS AND FURTHER WORK}

This study presented a comparison of normal and shear stresses between numerical and analytical analysis, and generally obtained a good agreement for CLT beams loaded in-plane. Only the net section of the beam was included to verify bending normal stresses, and this included only the layers in the stress direction. This assumption appears reasonable given the good agreement obtained between the limited number of results. Numerical results were obtained between analytical methods I and II to verify shear stresses and the case of FM I while in case of FM II the results indicated better agreement with method I. The results revealed that analytical method II highly overestimated the net shear stresses $\tau_{x y, g o}$ in case of FM II. Additionally, the influence of board width was not highly emphasized in FM I and FM II. In case of FM III, torsional shear stresses were observed between the analytical method I and II in most cases. The main difference was related to the distribution of shear stresses $I_{\mathrm{Zx}}$ relative to the crossing areas per height of the CLT beam in which the maximum value is observed in middle of beam height, and this contradicts the analytical assumption. Hence, the expression of an interaction between torsional and unidirectional shear stresses of FM III is questionable. Given the presented limited number of models, the agreement between mean values is acceptable although high stress concentrations were obtained at the gaps between the boards. Furthermore, the influence of board width and type of lay-up with or without double centric layer corresponded to critical parameters in FM III in numerical and analytical analyses, respectively. The presented analyses are a first attempt to contribute to the on-going review process of Eurocode 5 with respect to CLT beams loaded-in plane. Currently, regulations on designing these types of beams do not exist, and thus further experimental and numerical investigations are planned in the future.

\section{References}

[1] EN 1995 (Eurocode 5) 2004: Design of timber structures - Part 1-1: General rules and rules for buildings, European Committee for Standardization (EN 1995-1-1).

[2] Brandner R.; Flatscher G.; Ringhofer A.; Schickhofer G.; Thiel A. 2016: Cross laminated timber (CLT)- overview and development, European Journal of Wood and Wood Products, 74 (3), pp. 331-351, https://doi.org/10.1007/s00107-0150999-5

[3] Schickhofer G.; Bogensperger T.; Moosburger T. 2010: BSPhandbuch (CLThandbook: solid timber construction technique with cross laminated timber - verification base on new European standardization concept), Technical University of Graz.

[4] Brandner R.; Dietsch P.; Droscher J.; Schulte-Wrede M.; Sieder M. 2015: Scheibenschub von Brettsperrholz: Verifizierung einer Prüfkonfiguration und Parameterstudie, Bautechnik, 92(11), pp. 759-769, https://doi.org/10.1002 I bate. 201500078

[5] Flaig M. 2015: In Plattenebene beanspruchte Biegeträger aus Brettsperrholz, Teil 1: Effektive Festigkeits- und Steifigkeitskennwerte für die Schubbemessung, Bautechnik, 92(11), pp. 741-749, https://doi.org/10.1002 / bate.201500066

[6] Moosbrugger T.; Guggenberger W.; Bogensperger T. 2006: Cross Laminated Timber Wall Segments under homogeneous Shear - with and without Openings, Proceedings of 9th World Conference on Timber Engineering, Portland.

[7] Bogensperger T.; Moosbrugger T.; Silly G. 2010: Verification of CLT-plates under loads in plane, Proceedings of $11^{\text {th }}$ World Conference on Timber Engineering, Riva del Garda.

[8] Andreolli M.; Rigamonti M.A.; Tomasi R. 2014: Diagonal compression test on cross laminated timber panels, Proceedings of $13^{\text {th }}$ World Conference on Timber Engineering, Quebec.

[9] Flaig M; Blaß H.J. 2013: Shear strength and shear stiffness of CLT-beams loaded in plane, Proceedings of $46^{\text {th }}$ CIB-W18 Meeting, Vancouver.

[10] Jelec M.; Rajcic V.; Danielsson H.; Serrano E. 2016: Structural analysis of in-plane loaded CLT beams with holes: FEanalyses and parameter studies, Proceedings of 3 rd INTER Meeting, Graz.

[11] Gehri E. 2010: Shear problems in timber engineering - Analysis and solutions, Proceedings of $11^{\text {th }}$ World Conference on Timber Engineering, Riva del Garda.

[12] EN 14080 (2013) Timber Structures - Glued laminated timber and glued solid timber - Requirements (CEN).

Jeleč, M, Strukar, K, Rajčić, K 